\title{
Indirect cost rules seek to deflect threat of 'capping'
}

Washington. The Clinton administration has moved to deflect an imminent congressional attack on the government's funding of indirect university research costs by publishing new rules standardizing the basis on which they are assessed.

But some university researchers fear that the new rules - published in the Federal Register on 6 February - lack the clarity and simplicity needed to convince Congress that the $\$ 3$ billion reimbursed to universities by the federal government each year to cover such costs is being properly spent.

Congress has long been concerned about the differences in overhead costs charged by universities, which can vary from one-third to almost two-thirds of direct research costs. Of $\$ 12$ billion spent by the federal government on university research this year, $\$ 3$ billion was supposed to cover indirect costs. A budget proposal attached to last November's Republican election manifesto, the Contract with America, pledged to cut this by 10 per cent.

The élite private research universities tend to charge the most, and thus fear a congressional attempt to 'cap' the indirect cost rate. Public universities often pay for their facilities out of state funds, and therefore charge lower overhead rates.

The administration's new proposals, worked out after extensive consultation with the research universities, would set benchmarks for the cost of buildings and utilities in different regions of the United States, to be used to set limits on the costs researchers could recover. They would also set tighter rules for recovering the depreciation costs of new buildings.

The rules would also - somewhat optimistically - eliminate the term 'indirect costs' from official discussion, referring instead to 'research administration' and 'research facilities' costs.

The proposals remain controversial. Sam Silverstein, chair of the department of physiology and cellular biophysics at Columbia University, New York and president of the Federation of American Societies for Experimental Biology (FASEB), the biomedical research lobby group, says that the proposals are incomplete and too complex. Even though he feels that "the administration is broadly on the right track", he predicts the proposals will prove "too little and too late" to avoid "misdirected and harmful legislative action" in Congress this year.

But they have been welcomed by university administrators as indicating the administration's readiness to oppose the capping of indirect research costs. Interested parties have two months to comment on the administration's proposals.

C. $\mathbf{M}$.

\section{White House under fire over lack of clear priorities...}

Boston. Leading US industrialists last week criticized Jack Gibbons, science and technology adviser to President Bill Clinton, for failing to set sufficiently clear priorities in the science budget for the 1996 financial year, which starts on 1 October.

Several industrial representatives attending a policy forum at Massachusetts Institute of Technology (MIT) called on the science community to accept that some areas have reached 'maturity' and should be run down, allowing more promising fields to prosper.

In particular, James Vincent, chief executive of the biotechnology company Biogen, and William Brinkman, head of physical science research at AT\&T, both accused scientists - as well as Gibbons' science policy apparatus - of failing to make the kind of tough choices that the private sector has had to make in recent years.

Vincent said that scientists were expending too much "heat" on asking for more money, and not shedding enough "light" on ways in which the money could best be spent. "Everyone wants to get more of the pie, and frankly I get fed up with it," he said.

He predicted that the Republican-dominated Congress would ignore pleas for more money coming simultaneously from all fields of science. Instead, scientists should concentrate on helping Congress to identify priorities for support - and for cuts.

Brinkman said that AT\&T is already cutting back on physics research, even though this had provided the basis of the recent information revolution, in order to concen- trate on pressing problems in software and systems engineering.

He claimed that scientists are "glossing over the problem when we say we'll keep everything going and don't know where the breakthroughs will come from". Brinkman added that condensed-matter physics is now a mature field. "We can decide which fields are mature and which are not. And we haven't done it."

In contrast, however, most of the 200 scientists at the forum - organized by Charles Vest, president of MIT, and held the day after Clinton's budget proposals were released - appeared to support the Clinton administration's cautious efforts to back basic research on all fronts simultaneously.

"You have to be very careful when you think you know what frontiers we ought to be working on," said Gibbons. He pointed out, for example, that when he had worked in nuclear physics, many of his colleagues dismissed optical spectrometry as a research backwater, but that it had later played a critical role in telecommunications.

Frank Rhodes, president of Cornell University and chairman of the National Science Board, which is responsible for the National Science Foundation, expressed disappointment with the \$73-billion science budget proposed by the White House for next year, saying that it failed to specify research priorities. He also questioned the effectiveness of the National Science and Technology Council, the body set up by Gibbons to establish a national science policy. Colin Macilwain

\section{... as Congress finds its first victims}

Washington. Budget-cutters in the new US Congress found their first victims in the science and technology budget last week, as the House of Representatives Appropriations Committee recommended rescinding more than $\$ 3$ billion in federal funds that had already been granted to several federal agencies in 1995 and earlier years. The rescission was needed to pay for a supplemental package of defence spending.

Among the casualties was the Commerce Department's Advanced Technology Program (ATP), a special target of Republicans opposed to government/industry cooperation. The appropriations panel recommended cutting $\$ 107$ million, about a quarter of the ATP's 1995 budget, effectively preventing any new industrial partnerships beyond those already existing (see Nature 373, 374; 1995).

Claiming that "the record of defense conversion has not been a good one", the committee also slashed the Defense Depart- ment's Technology Reinvestment Program by $\$ 502$ million, and rescinded another $\$ 35$ million from defence conversion activities.

The panel cut $\$ 100$ million from the Department of Energy (DoE) and \$150 million from the Defense Department for environmental restoration activities not directly related to cleaning up defence laboratories. DoE's clean coal technology programme also took a cut of $\$ 200$ million out of a $\$ 2.75$ billion budget.

The National Aeronautics and Space Administration loses $\$ 400$ million earmarked for construction of two new wind tunnels. The Clinton administration included no additional money for the project in its 1996 budget request, prompting the Appropriations Committee to delete it.

The rescission bill now moves to the full House and then on to the Senate, where it is expected to be adopted. Another harsher rescission package is expected from the committee next month. Tony Reichhardt 